\title{
KONSELING KELUARGA DALAM MENGEMBANGKAN NILAI-NILAI KEARIFAN LOKAL PADA POLA PIKIR ANAK
}

\author{
Aisyah Khumairo \\ Program Studi PGMI FTIK LAIN Metro \\ Jl. Ki Hajar Derwantara 15A Iring Mulyo Kota Metro \\ e-mail:aisyahkbumairo8@gmail.com
}

\begin{abstract}
Family as the first and the nearest environment has primary responsibility in the value of education to children. Parenting activities conducted by parents in the family is one form of educational process of cultural values as a whole. The importance of multicultural education given to children early with the hope that the child is able to understand that in their environment and also in other environments are cultural diversity. The present article intends to provide an overview and ideas on family counseling in developing local knowledge in the mindset of children by conducting a literature review that looked at family counseling can become an alternative program to realize the love child of the local culture. There are two approaches to do in this case: 1). Individual approach or also called individual counseling which attempts to explore emotions, experiences and thoughts klien. 2). Family Conseling, discussion in families led by a family counselor.
\end{abstract}

Key word: family conseling, local wisdom, child's mindset

\begin{abstract}
Abstrak
Keluarga sebagai lingkungan yang pertama dan terdekat mempunyai tanggung jawab utama dalam pendidikan nilai kepada anak. Aktivitas pengasuban yang dilakukan orang tua dalam keluarga merupakan salah satu bentuk proses pendidikan nilai-nilai budaya secara keseluruban. Pendidikan multikultural sangat penting diberikan kepada anak sejak dini dengan harapan agar anak mampu memahami bahwa di dalam lingkungan mereka dan juga di lingkungan lain terdapat keragamaan budaya. Tulisan ini hadir bermaksud memberikan gambaran dan pemikiran mengenai konseling keluarga dalam mengembangkan kearifan lokal pada pola pikir anak dengan melakukan kajian literatur yang memandang konseling keluarga mampu menjadi program alternatif dalam merwujudkan kecintaan anak terbadap budaya lokal. Ada dua pendekatan dilakukan dalam hal ini: 1). Pendekatan individual atau juga disebut konseling individual yaitu upaya menggali emosi, pengalaman dan pemikiran konseli (anak). 2). Pendekatan kelompok (family conseling), yaitu diskusi dalam keluarga yang dibimbing oleh konselor keluarga.
\end{abstract}

Kata kunci: Konseling Keluarga, Kearifan Lokal, Pola Pikir Anak 


\section{Pendahuluan}

Di era globalisasi sekarang ini masalah yang penting mendapat perhatian adalah identitas kebangsaan. Derasnya arus globalisasi menyebabkan terkikisnya nilai-nilai kebangsaan. Anak-anak lebih bangga dengan budaya asing daripada budaya bangsanya sendiri. Hal ini dibuktikan dengan adanya rasa bangga yang lebih pada diri anak manakala menggunakan produk luar negeri, dibandingkan jika menggunakan produk bangsanya sendiri. Slogan "aku cinta buatan Indonesia" sepertinya hanya menjadi ucapan belaka, tanpa ada aksi yang mengikuti pernyataan tersebut. Selain itu, sekolah-sekolah berstandar internasional dengan segala keunggulannya, yang bahkan menggunakan bahasa Inggris sebagai pengantar sehari-hari dalam mendidik anak bangsa, bukan tidak mungkin menyebabkan kecintaan pada nilai budaya bangsa mulai pudar.

Tujuan pendidikan nasional jelas telah meletakkan dasar-dasar yang kuat dalam menopang pembangunan karakter dan jati diri bangsa. Namun, penyelenggaraan pendidikan telah mengalami degradasi yang sangat mengkhawatirkan, dimana nilai-nilai kearifan lokal telah terbungkus oleh kuatnya arus pendidikan global, kecerdasan pribadi intelektual menjadi ukuran yang lebih dominan untuk menentukan keberhasilan dalam menempuh pendidikan, dan upaya penyeragaman kemampuan telah membelenggu tumbuh dan berkembangnya keragaman kemampuan sebagai pencerminan beragamnya kekayaan budaya bangsa. Akibatnya, menipisnya tatakrama, etika, dan kreatifitas anak bangsa menjadi fenomena yang perlu mendapat perhatian serius dalam menata pendidikan di masa yang akan mendatang. Dalam hal lainnya, bangsa Indonesia lebih banyak berperan menggunakan teknologi daripada penghasil. Lemahnya karakter ini tak lain dikarenakan lemahnya individu memegang teguh nilai-nilai utama, terutama yang berbasis kearifan lokal.
Pentingnya pendidikan multikultural diberikan kepada anak sejak dini dengan harapan agar anak mampu memahami bahwa di dalam lingkungan mereka dan juga di lingkungan lain terdapat keragamaan budaya. Keragaman budaya tersebut berpengaruh terhadap tingkah laku, sikap, pola pikir manusia sehingga manusia tersebut memiliki cara-cara (usege), kebiasaan (folk ways), aturanaturan (mores) bahkan adat istiadat (customs) yang berbeda satu sama lain. Bila perbedaan itu tidak dapat dipahami dengan baik dan diterima dengan bijaksana, maka konflik akan mudah terjadi di masyarakat.

Perkembangan dan sosialisasi anak tergantung pada orang yang berinteraksi dengan anak, tempat mereka menghabiskan waktu bersama, dan peran permainan anak-anak. Perkembangan Pola Pikir adalah cara otak dan akal menerima, memproses, menganalisi, mempersepsi, dan membuat kesimpulan terhadap informasi yang masuk melalui indra. Salah satu unsur penting pembentukan pola pikir adalah informasi. Ini dapat berupa pemikiran yang dibungkus dalam nasihat orang tua, guru, orang lain, atau pemikiran dari elit agama. Selaras dengan pendapat John C. Maxwell “Dengan menabur pola pikir maka Anda akan menuai tindakan, dengan menabur tindakan maka Anda akan menuai kebiasaan, dengan menabur kebiasaan maka Anda akan menuai karakter, dengan menabur karakter maka Anda akan menuai masa depan. ${ }^{1}$

Pola pikir itu sangat dipengaruhi oleh faktor pendidikan, pengalaman, dan nilai-nilai yang dianut di lingkungannya. Sehubungan dengan itu salah satu elemen yang ikut bertanggungjawab adalah keluarga. Keluarga merupakan unit terkecil dalam masyarakat yang memegang peranan penting dalam pembentukan kepribadian anak hingga menjadi dewasa. ${ }^{2}$ Karena itu keluarga sebagai lembaga

${ }^{1}$ Eric B. Shiraev \& David A. Levy, Psikologi Lintas Kultural - Pemikiran Kritis dan Terapan Modern (Edisi Keempat), (Jakarta: Kencana, 2014), hlm. 233

${ }^{2}$ Sri Lestari, Psikologi Keluarga: Penanaman Nilai dan Penanganan Konflik dalam Keluarga, (Jakarta: Kencana, 2012) hlm. 31 
pertama dalam kehidupan anak akan memberikan pola dan corak bagi konsep diri anak yang berbedabeda sesuai dengan perkembangannya. Pengalaman interaksi dalam keluarga akan menentukan pola tingkah laku anak terhadap orang lain dalam masyarakat.

Nilai yang dimiliki individu merupakan produk dari pengalaman pribadi dan nilai-nilai budaya bersama yang ada di lingkungan tempat tinggalnya. Nilai menjadi pedoman atau prinsip umum yang memandu tindakan. Hal ini yang menjadi tugas pendidikan yang ada di dalam keluarga. Greenfield dan Suzuki mengatakan bahwa dalam menyampaikan nilai-nilai, harapan dan kebiasaan, keluarga juga menyampaikan pada anak pola-pola perilaku tertentu yang beragam menurut budaya dan kesukuan. ${ }^{3}$ Keluarga Sebagai lingkungan yang pertama dan terdekat mempunyai tanggung jawab utama dalam pendidikan nilai kepada anak. Aktivitas pengasuhan yang dilakukan orang tua dalam keluarga merupakan salah satu bentuk proses pendidikan nilai-nilai budaya secara keseluruhan.

Nilai-nilai kearifan lokal merupakan pembelajaran yang bersifat abstrak, maka orang tua harus mampu mengemas pola pengasuhan dan pendidikan keluarga yang berkualitas agar anakanak dapat diterima dan dapat bersosialisasi dengan baik di lingkungannya. Selain itu, sesuai dengan proses perkembangan pola pikir pada anak, sejak dari lahir terjadi melalui beberapa proses, yaitu proses kognitif yang menyangkut kegiatan berpikir, menalar, belajar dan memecahkan masalah. Dan apabila Orang tua akan memahami pola pikir anak harus melalui proses tersebut.

Kehidupan masyarakat khususnya keluarga, tidak akan pernah lepas dari sistem nilai yang ada di masyarakat tertentu. Sistem nilai menentukan perilaku anggota masyarakat. Berbagai sistem nilai

${ }^{3}$ Ibid hlm. 70 ada di masyarakat dengan berbagai permasalahannya, yaitu: ${ }^{4}$

1. Nilai agama saat ini degradasi terhadap agama sangat terasa sekali, semua agama merasakan bahwa kebanyakan umatnya kurang setia pada agama yang dianutnya.

2. Degradasi nilai adat istiadat, yang sering disebut tata susila atau kesopanan, hal ini dapat dibuktikan pada perilaku anak-anak, remaja saat ini.

3. Degradasi nilai-nilai sosial, sebagaimana kita saksikan saat ini, masyarakat sangat individualis mementingkan diri sendiri dalam segala hal, enggan berbagi harta, pikiran , saran dan pendapat, tidak mau bergaul terutama dengan orang rendahan, memutusan tali silaturrahmi terutama dengan keluarga.

4. Degradasi kesakralan keluarga, seperti yang kita lihat saat ini banyak sekali kekisruhan keluarga, banyak sekali kasus suami membunuh istrinya, dan sebaliknya, ayah membunuh anaknya dan sebaliknya.

Bimbingan dan konseling melibatkan keluarga tidak hanya dalam konsultasi melainkan dalam proses konselingpun keluarga dilibatkan didalamnya, sehingga terlaksana konseling keluarga dengan fokus tujuan merubah atau mengembangkan potensi dan perkembangan anak dengan melibatkan semua anggota keluarga. Dengan membangun relasi dan komunikasi dalam suatu kegiatan konseling keluarga. Cara ilmiah dalam membantu proses mengembangan nilai-nilai kearifan lokal pada pola pikir anak adalah dengan cara konseling keluarga (family counseling). Family Counseling atau konseling keluarga adalah upaya bantuan yang diberikan kepada individu anggota keluarga melalui sistem keluarga (pembenahan komunikasi keluarga) agar potensinya berkembang seoptimal mungkin dan masalahnya dapat diatasi atas dasar kemauan

${ }^{4}$ Sofyan S. Wilis, Konseling Keluarga (Bandung: Alfabeta, 2011), hlm. 46 
membantu dari semua anggota keluarga berdasarkan kerelaan dan kecintaan terhadap keluarga.

Artikel ilmiah ini disajikan dengan tujuan untuk menambah khasanah para pendidik dan keluarga dalam mengembangkan pola mendidik anak agar memiliki jiwa nasionalisme yang tinggi. Maka dari itu perlu dibahas tentang konseling keluarga dalam mengembangkan nilai-nilai kearifan lokal pada pola pikir anak.

\section{Pembahasan}

\section{Pola Pikir Anak}

Mindset, istilah yang lebih dikenal menggantikan pola pikir. Pola pikir adalah cara otak dan akal menerima, memproses, menganalisis, mempersepsi, dan membuat kesimpulan terhadap informasi yang masuk melalui indra kita. Pola pikir seseorang akan mudah terlihat ketika menghadapi suatu permasalahan yang harus diselesaikan. Begitu juga dengan pola pikir anak. Dengan perkembangan usia anak, berbedaan usia beda pula cara berpikir anak tersebut. Mengenali anak SD berarti mengenali sosok anak-anak yang berusia 7- 12 tahun. Anak pada usia ini perkembangan kognitif yang terlihat, mereka berpikir lebih kompleks dan mulai memasuki pendidikan formal. Kehidupan sosial anak usia ini lebih mengutamakan pertemanannya. Berteman itu penting untuk membantu mereka bersosialisasi dengan lingkungan. Selain itu, anak hanya mampu berpikir dengan logika jika untuk memecahkan persoalan-persoalan yang sifatnya konkret atau nyata saja, yaitu dengan cara mengamati atau melakukan sesuatu yang berkaitan dengan pemecahan persoalan-persoalan tertentu, kemampuan untuk mengintropeksi diri sendiri, sehingga kesadaran diri sendiri tercapai, Kemampuan untuk membayangkan peranan-peranan yang diperankan sebagai orang dewasa. Kemampuan untuk menyadari dan memperhatikan kepentingan yang ada di masyarakat lingkungannya. ${ }^{5}$

Adapun faktor-faktor yang berpengaruh terhadap perkembangan berpikir anak tingkat sekolah dasar adalah sebagai berikut: ${ }^{6}$

\section{Faktor Heriditas}

Anak semenjak dari kandungan telah memiliki sifat-sifat yang menentukan daya kerja intelektualnya. Secara potensial anak telah membawa kemungkinan kemampuan berpikir normal, diatas atau dibawah normal. Namun keadaan potensial tidak akan terealisasi secara optimal apabila lingkungan kurang memberi kesempatan dan kurang memberi rangsangan yang sesuai.

\section{Faktor Lingkungan}

a. Keluarga

Keluarga sangat mempengaruhi perkembangan berpikir dikarenakan di keluargalah seorang anak mendapat pendidikan untuk pertama kalinya.

b. Sekolah

Sekolah merupakan wahana untuk mengembangkan daya cipta, karsa dan karya anak. Dengan sekolah, anak bisa berkembang secara lebih maksimal.

c. Masyarakat

Masyarakat merupakan tempat untuk menerapkan nilai dan norma yang telah diperkenalkan pada anak.

\section{Nilai-nilai Kearifan Lokal}

Nilai merupakan bagian penting dari pengalaman yang memengaruhi perilaku individu. Nilai meliputi sikap individu, sebagai standar bagi tindakan dan keyakinan. Nilai dipelajari

${ }^{5}$ Desmita, Psikologi Perkembangan (Bandung : Remaja Rosdakarya, 2009), hlm. 185

${ }^{6}$ Elizabeth B.Hurlock, Psikologi Perkembangan : Suatu Pendekatan Sepanjang Rentang Kehidupan (Jakarta: Erlangga, 2010), hlm. 378. 
dari keluarga, budaya dan orang-orang di sekitar individu. Nilai juga dapat menuntun individu dalam mengambil keputusan. Pendidikan nilai-nilai adalah suatu upaya nyata untuk mengajarkan nilai-nilai dan melatih keterampilan melakukan penilaianpenilaian. Terkait dengan keluarga, pendidikan nilai dapat didefinisikan sebagai proses yang diinisiasi oleh orang dewasa untuk mengembangkan anak melalui insight, pelatihan dan imitasi guna mempelajari kebiasaan dan nilai-nilai yang kongkuen dalam beradaptasi dengan budaya.

Menurut Arnett melalui interaksi orang tua dengan anak,orang tua tidak mengkreasi aktivitas pengasuhan secara pribadi, tetapi orang tua dan anak mengikuti aturan-aturan tentang peran orang tua yang ada dalam budaya yang telah dipelajarinya melalui pengalaman dan mempunyai pendidikan nilai sebelumnya. ${ }^{7}$ Selain itu karakteristik keluarga turut mempengaruhi corak nilai yang diinternalisasikan kepada anak. Berdasarkan struktur ada keluarga batih dan keluarga inti. Ditinjau dari status sosial ekonomi, ada perbedaan karakteristik antara keluarga kelas bawah, kelas menengah dan kelas atas. Di samping itu, orientasi etnis dan agama dari keluarga juga turut mempengaruhi pendidikan nilai kepada anak.

Heath mengungkapkan perlunya orang tua memperhatikan tiga tahapan dalam proses pendidikan nilai, yakni (1) Orang tua harus mengidentifikasi nilai-nilai pribadinya. (2) Orang tua harus mampu menghadapi konflik nilai. (3) Mendasarkan semua keputusan pengasuhan pada nilai-nilai pribadi orang tua. Selanjutnya, Superka, Ahrens dan Hedstrom di dalam bukunya Sri Lestari memaparkan lima pendekatan dalam pelaksanaan pendidikan nilai yaitu penanaman, perkembangan moral, analisis, klarifikasi nilai dan belajar tindakan. ${ }^{8}$

Budaya adalah sistem nilai dan kepercayaan yang dipegang secara bersama oleh beberapa orang

${ }^{7}$ Sri Lestari , Psikologi Keluarga: Penanaman Nilai dan Penanganan Konflik dalam Keluarga, (Jakarta: Kencana, 2012) hlm. 79

${ }^{8}$ Ibid,.hlm. 87 dan memberikan perasaan menjadi bagian dari kelompok atau rasa identitas. Dalam suatu budaya terjadi proses pewarisan budaya antar generasi, yang meliputi transmisi nilai, sikap, peran, dan produkproduk budaya lain dari generasi tua ke generasi yang lebih muda. Dalam keluarga, proses transmisi nilai terutama terjadi melalui pendidikan nilai oleh orang tua kepada anak.

Sementara itu, kearifan lokal berasal dari dua kata yaitu kearifan (wisdom), dan lokal (local). Secara umum maka local wisdom (kearifan setempat) dapat dipahami sebagai gagasan-gagasan setempat (local) yang bersifat bijaksana, penuh kearifan, bernilai baik, yang tertanam dan diikuti oleh anggota masyarakatnya. Kearifan lokal terbentuk sebagai keunggulan budaya masyarakat setempat maupun kondisi geografis dalam arti luas. Kearifan lokal merupakan produk budaya masa lalu yang patut secara terus-menerus dijadikan pegangan hidup. ${ }^{9}$

Meskipun bernilai lokal tetapi nilai yang terkandung di dalamnya dianggap sangat universal. Keberadaan kearifan lokal ini bukan tanpa fungsi. Kearifan lokal sangat banyak fungsinya. Seperti yang dituliskan Sartini (2006), bahwa fungsi kearifan lokal adalah sebagai berikut: ${ }^{10}$

1. Berfungsi untuk konservasi dan pelestarian sumber daya alam.

2. Berfungsi untuk pengembangan sumber daya manusia.

3. Berfungsi untuk pengembangan kebudayaan dan ilmu pengetahuan.

4. Berfungsi sebagai petuah, kepercayaan, sastra dan pantangan.

5. Bermakna sosial misalnya upacara integrasi komunal/kerabat.

6. Bermakna sosial, misalnya pada upacara daur pertanian.

7. Bermakna etika dan moral.

${ }^{9}$ Wuryandani, Wuri. "Integrasi Nilai-nilai Kearifan Lokal dalam Pembelajaran untuk Menanamkan Nasionalisme di Sekolah Dasar." Jurnal Pelangi Pendidikan Vol XI (2) (2011).

${ }^{10}$ Ibid 
8. Bermakna politik, misalnya upacara ngangkuk merana dan kekuasaan patron client

\section{Konseling Keluarga}

Keluarga merupakan pranata sosial yang memberikan legalitas memenuhi kebutuhan dasar biologis, berfungsi ekonomis, lingkungan pendidikan pertama dan utama bagi anak, penyemaian masyarakat masa depan karena keluarga adalah miniatur masyarakat, pelindung bagi anggota keluarga dari acaman fisik maupun psikologis, lingkungan yang memberi kenyamanan, kehangatan serta keceriaan, penanam nilai-nilai agama kepada anggota keluarga agar memiliki pedoman hidup yang benar.

Salah satu mendefinisikan keluarga yaitu dengan cara meninjau kembali dari segi fungsi keluarga. Suatu keluarga yang berfungsi secara sehat ialah suatu sistem sosial yang dapat: 1) memenuhi kebutuhan-kebutuhan para anggotanya. 2) suatu lingkungan yang cocok untuk reproduksi dan pengasuhan anak 3) meningkatkan kesejahteraan sosial dalam komunitas.

Cara keluarga itu disusun dan juga fungsifungsinya sangat dipengaruhi oleh ide-ide spiritual, etnis, rasial, kultural, sosial dan politis yang dianut oleh keluarga itu. Selain itu, di dalam keluarga itu sendiri menyimpan sejumlah memori dan dipengaruhi oleh sejarah dan pengalaman orang dewasa yang ada di dalamnya, juga ada nilai-nilai dan keyakinan, prasangka dan sifat-sifat personal yang lain sebagai individu dewasa anggota keluarga, dan berpengaruh kepada cara keluarga berperilaku. Faktor-faktor yang mempengaruhi fungsi keluarga:

1. Tahap-tahap perkembangan keluarga

2. Budaya/etnisitas

3. Proses dan perilaku dalam keluarga

Konseling keluarga pada dasarnya adalah penerapan konseling pada situasi yang khusus. Konseling keluarga ini secara khusus memfokuskan pada masalah-masalah yang berhubungan dengan situasi keluarga dan penyelenggaranya melibatkan anggota keluarga. Crane mengatakan bahwa konseling keluarga merupakan proses pelatihan terhadap orang tua dalam hal metode mengendalikan perilaku yang positif dan membantu orang dalam perilaku yang dikehendaki. Dalam pengertian ini konseling kelurga tidak bermaksud untuk mengubah kepribadian, sifat, dan karakter orang-orang yang terlibat, tetapi lebih mengusahakan perubahan dalam sistem keluarga melalui pengubahan perilaku.

Proses konseling keluarga berbeda dengan konseling individual karena ditentukan oleh berbagai faktor seperti jumlah kliennya (anggota keluarga) lebih dari seorang. Relasi antar anggota keluarga amat beragam dan bersifat emosional, dan konselor harus melibatkan diri (partisipan penuh) dalam dinamika konseling keluarga. Berdasarkan kenyataan, ada lima jenis relasi atau hubungan dalam konseling keluarga yaitu:

1. Relasi seorang konselor dengan konseli

2. Relasi satu konseli dengan konseli lainnya

3. Relasi konselor dengan sebagaimana kelompok

4. Relasi konselor dengan keseluruhan anggota keluarga dan

5. Relasi antar sebagaimana kelompok dengan sebagaimana kelompok anggota lain, misalnya ibu memihak anak laki-laki dan ayah memihak anak perempuan.

Proses komunikasi antara konselor dengan konseli (Keluarga : anak dan orang tua anak) dalam hubungan yang membantu, sehingga keluarga dan atau masing-masing anggota keluarga mampu membuat keputusan, merubah perilaku secara positif dan mengembangkan suasana kehidupan keluarga sehingga konstelasi keluarga berfungsi secara keseluruhan, meningkatkan ketahanan keluarga serta mengembangkan potensi masingmasing anggota keluarga sebagai pribadi maupun sebagai anggota keluarga. 
Tahapan pada konseling keluarga adalah :

1. Membangun relasi dengan keluarga dan masing-masing anggota keluarga

2. Mendiskusikan prinsip-prinsip konseling membuat komitmen

3. Menetapkan tujuan konseling serta peran masing-masing anggota keluarga untuk mencapai tujuan

4. Menggali permasalahan

5. Personalisasi

6. Menyusun rancangan tindakan, monitoring dan evaluasi

Keluarga memenuhi kebutuhan psikososial, mewariskan nilai-nilai budaya, berkecukupan dalam bidang ekonomi, mengamalkan nilai-nilai moral dan agama dan orang tua memiliki stabilitas ekonomi. Melalui Konseling, keluarga didorong untuk menjadi keluarga yang efektif yaitu keluarga yang memiliki budaya keluarga yang indah. Budaya keluarga yang indah ditandai dengan rasa memiliki dari seluruh anggota keluarga dengan tulus dan penuh cinta kasih, pemberian kesempatan bagi semua anggota untuk tumbuh dan berkembang, membangun masa depan keluarga, menjadikan keluarga sebagai prioritas, anggota keluarga saling mendukung dan menghormati dengan prinsip win-win solution, mengembangkan kekuatan dan ketahanan keluarga serta selalu memperbaharui semangat keluarga. ${ }^{11}$

\section{Model-model Konseling antar Anggota Keluarga}

Terdapat beberapa model konseling dalam kaitan relasi antar anggota keluarga, yaitu:

1. Teori sistem, meliputi ide bahwa keluarga adalah sistem yang berinteraksi

${ }^{11}$ Yusi Riksa Yustiana, Modul Pedoman Dan Materi Konseling Keluarga Penanggulangan Nafza Bagi Fasilitator Dengan Sasaran Orang Tua Dan Remaja, Jawa Barat: Badan Penanggulangan Nafza, Kenakalan Remaja, Prostitusi , 2000) dengan sistem yang lain dan mempunyai subsistem di dalamnya. Keluarga tentu saja mencoba homeostasis tetap untuk menjadi perubahan sementara waktu memerlukan ketidakstabilan sebelum mencapai homeostasis yang baru. Terapi keluarga multigenerasi menempatkan tekanannya pada cara pola-pola perilaku yang berlaku dari generasi ke generasi. Terapi keluarga strategis didasarkan pada sibernetik, struktural dan keteranganketerangan fungsional keluarga.

2. Konseling relasi terpadu model CACHO. Kelemahan eklektivisme ialah bisa menjadi kurang konsisten secara klinis karena strategi dan teknik yang dipilih dipaksakan demi sebuah situasi khusus. Dalam peminjaman selektif digunakan suatu model tertentu, sementara teknik dan strategi dipinjam dari pendekatan lain. Hal ini menggambarkan ciri khas batasan suatu teori mengubah tingkah laku. Model terpadu CACHO didasarkan pada teori mengubah tingkah laku gestalt pada situasi tertentu.

3. Penggunaan mitra terapis dan atau tim pemantul.

Memberikan informasi baru membantu meningkatkan kesadaran, adanya mitra terapis atau tim pemantul sangat menguntungkan bagi diperolehnya informasi tambahan. Penggunaan mitra terapis dan tim pemantul sangat bermanfaat dalam merancang pelatihan yang berkualitas tinggi dan pengawasan yang berkelanjutan.

4. Keterampilan konseling relasi

Konseling relasi perlu menguasai sederet keterampilan konseling tradisional. Mengeksternalisasi masalah menghilangkan konotasi-konotasi negatif 
tentang seseorang atau keluarga sehingga masalah dapat ditangani.

Dalam kesehariannya seluruh anggota keluarga saling berinteraksi, tentunya mereka saling mempengaruhi dan dipengaruhi. Memusatkan perhatian pada pola-pola interaksi relasi selama konseling dengan suatu keluarga perlu menaruh perhatian terhadap proses komunikasi dan bagaimana anggota keluarga berbicara dan berelasi satu sama lain. Di dalam proses interaksi terdapat beberapa konsep yaitu:

1. Hemoistasis yaitu pengaturan diri agar sistem bisa memelihara diri dalam suatu keadaan keseimbangan dinamis.

2. Karualitas linier dan sirkuler yaitu situasi yang ada saat peristiwa satu mempengaruhi peristiwa yang lain.

Di dalam bentuk interaksi dalam keluarga terdapat teori kelekatan yakni teori yang menganggap bahwa para bayi menjadi melekat kepada ibunya atau orang lain yang dapat memberi kontak dan kenyamanan. Dalam upaya melakukan konseling keluarga seseorang harus melakukan kontak awal dengan keluarga sebelum memulai konseling. Proses konseling membantu keluarga berkomunikasi pada sesi pertama. Hal yang pertama yang harus dilakukan seorang konselor ialah mengidentifikasi masalah pribadi konseli. Informasi yang diterima sebelum pertemuan keluarga secara umum hanyalah suatu sudut pandang pribadi. Tujuan utama konseling ialah mendorong keluarga untuk saling menyampaikan aneka gambaran masing-masing atas keluarga dan cara berfungsinya. Selain itu, meningkatkan kesadaran atas dinamika keluarga tujuan jangka panjang dalam konseling relasi keluarga ialah meningkatkan kesadaran atas apa yang ada. Intervensi-intervensi konseling meliputi penggunaan pertanyaan-pertanyaan sirkuler, memberikan umpan balik, dan membuat informasi patut diperhatikan.

\section{Konseling Relasi untuk Anak}

Anak-anak memiliki dunia yang berbeda dari orang dewasa dan berada pada tingkat perkembangan yang berbeda. Menurut Sharry Anak-anak suka berkomunikasi melalui permainan dan kegiatan-kegiatan kreatif dan juga melalui cerita. Saat melaksanakan praktik konseling untuk anak perlu digunakan media dari kegiatan yang dipadukan dengan keterampilan-keterampilan konseling.

Konseling anak melibatkan penggunaan media dan kegiatan dibarengi dengan penguasaan keterampilan-keterampilan konseling. Lempung atau tanah liat dalam digunakan dalam berbagai cara untuk membantu mencermati relasi-relasi saudara kandung.

Membantu anak untuk bicara tentang relasinya untuk membantu memecahkan prolem-probelm relasi anak. Seorang konselor perlu membantu membangun relasi yang bisa dipercaya dengan anak.

1. Para konselor yang menangani anak-anak harus dilatih dengan tepat.

Akan sangat menguntungkan jika konselor relasi yang mmenangani anak adalah orang yang professional.

2. Membuat perjanjian dengan orang tua

Saat mulai perjanjian dengan kedua orang tua, ketika konselor yang sedang menangani keluarga perlu mendiskusikan dengan mereka kemungkinan-kemungkinan untuk memberikan sesi-sesi konseling individual untuk anak yang dilaksanakan oleh anggota tm yang lain, yang bertindak sebagai konselor.

3. Ada batasan-batasan bagi kerahasiaan

a. Tujuan konseling individual adalah membantu anak untuk mengerti mengapa mereka perlu menggunakan waktunya untuk konseling dapat dilakukan paling baik saat kehadiran orang tua. Atau saat lain dalam kehadiran seluruh keluarga. 
b. Sifat-sifat seorang konselor anak. Seorang konselor untuk anak-anak harus tulus, mengikuti sifat kanak-kanak yang ada dalam dirinya, menerima dan tidak berprasangka secara emosional. Anakanak sangat pandai mengenal orang-orang yang tidak tulus yang mencoba memainkan sebuah peran yang tidak konsisten dengan bagian lain dari kepribadiannya.

Seorang konselor mampu melibatkan diri dengan sang anak diantara nya dengan (1) menciptakan suatu relasi saling mempercayai (2) menyeleksi dan menggunakan media atau kegiatan (3) memberikan fasilitas-fasilitas dan kesempatan-kesempatan melakukan permainan yang bebas dan bermakna (4) menggunakan keterampilan-keterampilan konseling anak yang tepat.

Selain itu seorang konselor mampu mengarahkan anak agar merasa aman dalam situasi konseling diantaranya dengan menggunakan cara (1) pengamatan (2) membuat pertanyaan-pertanyaan (3) pendengar aktif (4) menggunakan pernyataan-pernyataan.

c. Menggunakan media dan kegiatan dengan keterampilan konseling

d. Menggunakan media atau kegiatan tertentu sehingga minat anak tersalurkan dan mereka mampu menggunakan media atau kegiatan itu untuk membantunya memusatkan diri pada apa yang penting bagi mereka.

Implementasi konseling keluarga untuk mengembangkan nilai-nilai kearifan lokal pada pola pikir anak

Hubungan keluarga sangat besar pengaruhnya dalam perkembangan kepribadian anak-anak. Pandangan anak-anak tentang diri mereka sendiri merupakan cerminan langsung dari apa yang dinilai dari cara mereka diperlakukan oleh anggota-anggota keluarganya. Maka dari itu konseling keluarga sangat diperlukan dan memiliki peranan penting dikarenakan konseling keluarga dikhususkan memfokuskan masalah-masalah yang berhubungan dengan situasi keluarga dan penyelenggaraanya melibatkan anggota keluarga. Konseling keluarga diarahkan untuk membantu anak agar dapat beradaptasi lebih baik untuk mempelajari lingkungannya melalui perbaikan lingkungan keluarganya. Konseling ini sangat efektif terutama untuk mengatasi masalah-masalah anak yang berhubungan dengan sikap dan perilaku orang tua sepanjang berinteraksi dengan anak. Salah satu komponen yang dimaksudkan adalah pola pengasuhan anak. Perkembangan dan sosialisasi anak tergantung pada orang yang berinteraksi dengan anak, tempat mereka menghabiskan waktu bersama, dan peran permainan anak-anak. Tradisi kultural dari kolektivisme berkorelasi positif dengan gaya parenting otoriter yang didasarkan pada tuntutan yang ketat, kontrol perilaku dan sanksi tegas.

Setiap kultur, memberikan seperangkat norma tentang relasi orang tua-anak. Secara lintas kultural, pemikiran anak itu penuh harapan. Setiap perkembangan anak dipengaruhi oleh praktik sosial, nilai sosial dan tuntutan dari orang tua. Nilai-nilai kebudayaan merupakan pandanganpandangan mengenai apa yang dianggap baik dan apa yang dianggap buruk. Nilai-nilai itu berasal dari pengalaman manusia berinteraksi dengan sesamanya. Selanjutnya, nilai-nilai itu akan berpengaruh pada pola pikir manusia, yang kemudian menentukan sikapnya.

Psikolog Swiss Jean Piagen menjelaskan cara anak mengembangkan proses berpikir tentang dirinya dan dunia sekitarnya. Selama masa kanakkanak pertengahan, yang berlangsung kira-kira usia 6-12 tahun, anak terus mengembangkan keterampilan berpikir dan sosial. Pemikiran abstrak 
mulai berperan lebih banyak dalam kehidupan sehari-hari. Tetapi pemikiran anak terutama didasarkan pada observasi dan pengalaman langsung. Jika sesuatu dapat dilihat dan diamati, ia akan mudah dipahami dan diinterpretasikan. Para ahli psikologi dan pendidikan belakangan ini semakin menyadari bahwa anak-anak di sekolah tidak hanya harus mengingat atau menyerap secara pasif informasi baru, melainkan mereka perlu berbuat lebih banyak dan belajar bagaimana berpikir secara kritis. Anak harus memiliki kesadaran akan diri dan lingkungannya. Menurut Perkins, Jay dan Tishman yang di kutip dalam bukunya desmita bahwa pemikiran yang baik meliputi 1) berfikir terbuka, fleksibel, dan berani mengambil resiko. 2) mendorong keingintahuan intelektual. 3) mencari dan memperjelas pemahaman.4) merencanakan dan menyusun strategi. 5) berhati-hati secara intelektual, 6) mencari dan mengevaluasi pertimbanganpertimbangann rasional dan 7) mengembangkan metakognitif.

Menurut Erikson, individu berkembang melalui serangkaian krisis psikologis. Setiap krisis atau konflik, muncul dari kebutuhan untuk beradaptasi dengan lingkungan sosial dan krisis itu akan mengembangkan rasa kompetensi. Setelah krisis dipecahkan, individu akan bergerak lebih maju. Usaha untuk mengembangkan kemampuan berpikir:

1. Berusaha memecahkan sendiri setiap masalah yang dihadapi.

2. Aktif mengikuti kegiatan-kegiatan positif di lingkungan

3. Ikut berpartisipasi aktif dalam kegiatan kemasyarakatan

4. Bersikap mandiri, dewasa, dan kreatif

5. Mau membuka hati untuk menghadapi hal-hal yang baru

6. Mau berusaha menjadi pribadi yang lebih baik

7. Tak mudah putus asa

\section{Bersikap positif}

Anak-anak memiliki dunia yang berbeda dari orang dewasa dan berada pada tingkat perkembangan yang berbeda. Menurut Sharry Anak-anak suka berkomunikasi melalui permainan dan kegiatan-kegiatan kreatif dan juga melalui cerita. Dalam melaksanakan praktik konseling untuk anak perlu digunakan media dari kegiatan yang dipadukan dengan keterampilan-keterampilan konseling diantaranya yaitu:

1. Menangani anak usia 7 tahun keatas menggunakan miniatur hewan-hewan

a. Mainan dikaitkan dengan sifat-sifat dari makhluk ada yang tampak agresif, bersahabat, sebagian kelihatan tidak bersahabat, tidak agresif dan lebih puas diri.

b. Menggunakan hewan miniatur untuk mencermati komunikasi-komunikasi dalam keluarga

c. Menggunakan miniatur hewan bisa menguak problem-problem relasi keluarga yang mempengaruhi anak menjadi terbuka. Sehingga anak dapat berbicara

2. Menangani anak usia 5 sampai 7 tahun menggunakan simbol-simbol dalam baki pasir, lempung atau tanah liat yang digunakan berbagai cara untuk membantu mencermati relasi-relasi saudara kandung.

a. Relasi keluarga dapat dicermati lebih lanjut dalam baki pasir seperti diilustrasikan oleh peristiwa-peristiwa dan situasi-situasi khusus.

b. Memberikan waktu untuk anak melakukan pekerjaan di tanah

c. Menggunakan simbol-simbil dalam baki pasir membuka isu-isu relasi keluarga yang mempengaruhi anak sehingga sang anak mampu membicarakan hal ini.

3. Menangani anak-anak dibawah usia 5 tahun dengan menggunakan permainan pura-pura 
yang imajinatif seperti perabotan kecil yang akrab dalam keseharian, boneka dan mainan yang berkaitan denganya. Dan bahan-bahan pakaian.

a. Anak-anak dalam permainan berpura-pura yang imajinatif diilhami oleh pengalamanpengalaman anak itu sendiri.

b. Anak kecil secara ilmiah menggunakan permainan pura-pura imajinatif anak-anak tidak berdaya jika tidak diberi pilihan.

\section{Kesimpulan}

Tujuan pendidikan nasional jelas telah meletakkan dasar-dasar yang kuat dalam menopang pembangunan karakter dan jati diri bangsa. Namun, penyelenggaraan pendidikan telah mengalami degradasi yang sangat mengkhawatirkan, dimana nilai-nilai kearifan lokal telah terbungkus oleh kuatnya arus pendidikan global, kecerdasan pribadi intelektual menjadi ukuran yang lebih dominan untuk menentukan keberhasilan dalam menempuh pendidikan, dan upaya penyeragaman kemampuan telah membelenggu tumbuh dan berkembangnya keragaman kemampuan sebagai pencerminan beragamnya kekayaan budaya bangsa. Keluarga merupakan pranata sosial yang memberikan legalitas memenuhi kebutuhan dasar biologis, berfungsi ekonomis, lingkungan pendidikan pertama dan utama bagi anak, penyemaian masyarakat masa depan karena keluarga adalah miniatur masyarakat, pelindung bagi anggota keluarga dari acaman fisik maupun psikologis, lingkungan yang memberi kenyamanan, kehangatan serta keceriaan, penanam nilai-nilai agama kepada anggota keluarga agar memiliki pedoman hidup yang benar. Ada dua pendekatan dilakukan dalam hal ini: 1). Pendekatan individual atau juga disebut konseling individual yaitu upaya menggali emosi, pengalaman dan pemikiran klien. 2). Pendekatan kelompok (family conseling). Yaitu diskusi dalam keluarga yang dibimbing oleh konselor keluarga.

\section{Daftar Pustaka}

Desmita. Psikologi Perkembangan. Bandung : Remaja Rosdakarya, 2009.

Elizabeth B.Hurlock. Psikologi Perkembangan : Suatu Pendekatan Sepanjang Rentang Kehidupan. Jakarta: Erlangga, 2010.

Eric B. Shiraev \& David A. Levy. Psikologi Lintas Kultural - Pemikiran Kritis dan Terapan Modern (Edisi Keempat). Jakarta: Kencana, 2014.

Sofyan S. Wilis. Konseling Keluarga. Bandung: Alfabeta, 2011.

Sri Lestari. Psikologi Keluarga: Penanaman Nilai dan Penanganan Konflik dalam Keluarga. Jakarta: Kencana, 2012.

Wuryandani, Wuri. Integrasi Nilai-nilai Kearifan Lokal dalam Pembelajaran untuk Menanamkan Nasionalisme di Sekolah Dasar.Jurnal Pelangi Pendidikan, Vol XI (2), 2011.

Yusi Riksa Yustiana. Modul Pedoman Dan Materi Konseling Keluarga Penanggulangan Nafza Bagi Fasilitator Dengan Sasaran Orang Tua Dan Remaja, Jawa Barat: Badan Penanggulangan Nafza, Kenakalan Remaja, Prostitusi , 2000. 